\title{
COMPOSITIONAL CHARACTERISTICS AND Ta-Sn-Nb RARE METAL MINERALIZATION POTENTIAL OF EGBE PEGMATITE, SOUTHWESTERN NIGERIA.
}

\author{
ADEROGBIN, J. A. AND OKUNLOLA O. A.
}

(Received 24 January 2019; Revision Accepted 13 June 2019)

\begin{abstract}
Pan African $(600 \pm 150)$ pegmatite which intrudes gneisses, amphibolites, quartzite and schists around Egbe area were studied for their compositional features. This is with a view to characterizing and assessing their potential for rare metal Ta-Sn-Nb mineralization. Twenty seven samples comprising eleven (11) whole rock, sixteen (12) muscovite extracts and four (4) feldspar extracts samples were analyzed using the Inductively Coupled Plasma Atomic Emission Spectrometry (ICP-AES). Major oxide geochemical assessment of the whole rock pegmatite indicates that the pegmatite is siliceous $\left(79.82 \% \mathrm{SiO}_{2}\right)$ and moderately high in $\mathrm{Al}_{2} \mathrm{O}_{3}(12.22 \%)$. The $\mathrm{K}_{2} \mathrm{O}, \mathrm{Na}_{2} \mathrm{O}$ contents are averagely $2.25 \%$ and $2.87 \%$ respectively while $\mathrm{Fe}_{2} \mathrm{O}_{3}, \mathrm{MnO}, \mathrm{MgO}$ are each less than $1.0 \%$.

Average values of trace elements in the pegmatite are Ta (52.55ppm), Sn (92.3 ppm), Rb (1083.5ppm), Nb (109.35 $\mathrm{ppm}), \mathrm{Cs}(32.12 \mathrm{ppm}), \mathrm{Sr}(17.84 \mathrm{ppm}), \mathrm{Y}(9.86 \mathrm{ppm})$, and $\mathrm{Zr}(41.27 \mathrm{ppm}), \mathrm{Ba}(50.47 \mathrm{ppm}), \mathrm{Hf}(12.38 \mathrm{ppm}), \mathrm{Zr}$ (41.27ppm), Ga (32.12ppm) and W(2.91PPM) and ratios of diagnostic elements are K/Rb (30.27), Rb/Sr (298.93), $\mathrm{Zr} / \mathrm{Hf}$ (7.23), Rb/Cs (65.80), K/Cs (1103.11), Ta/W (41.81), Nb/Ta (55.397) Na/Rb (41.77) and $\mathrm{Na} / \mathrm{K}(92.25)$

$\mathrm{A} / \mathrm{CAN}>1$ and $\mathrm{Al}_{2} \mathrm{O}_{3}>\mathrm{CaO}+\mathrm{Na}_{2} \mathrm{O}+\mathrm{K}_{2} \mathrm{O}$ with enrichment of $\mathrm{SiO} 2, \mathrm{Al}_{2} \mathrm{O}_{3}, \mathrm{Na}_{2} \mathrm{O}, \mathrm{K}_{2} \mathrm{O}$ and depletion of $\mathrm{Fe}_{2} \mathrm{O}_{3}, \mathrm{MnO}_{2}$ and $\mathrm{MgO}$ suggests that Egbe pegmatite is of peraluminous bulk composition and plots of $\mathrm{A} / \mathrm{NK}$ vs $\mathrm{Al} / \mathrm{CNK}$ and $\mathrm{Rb}$ vs $(\mathrm{Y}+\mathrm{Nb})$ discriminates Egbe pegmatite in the peraluminous LCT $(\mathrm{Li}, \mathrm{Rb}, \mathrm{Cs}, \mathrm{Be}, \mathrm{Ga}, \mathrm{Nb}<,>\mathrm{Ta}, \mathrm{Sn}, \mathrm{Hf}, \mathrm{B}, \mathrm{P}, \mathrm{F})$ of syncollisional to within plate granitic family. The Ta/W vs $C$ s plot for the three sample media shows the relationship between increasing $\mathrm{Ta} / \mathrm{W}$ ratio and elemental fractionation as indicated by $\mathrm{Cs}$. The $\mathrm{K} / \mathrm{Rb}$ vs $\mathrm{Cs}$ and $\mathrm{K} / \mathrm{Rb}$ vs $\mathrm{Rb}$ plots for the three sample media further establishes the rare - metal nature and mineralization potential of Egbe pegmatite. Using the discriminant plots of TaVs Rb, Ta vs $\mathrm{Cs} . \mathrm{TaVs} \mathrm{K} / \mathrm{Cs}$, and $\mathrm{Ta} \mathrm{Vs}(\mathrm{Cs}+\mathrm{Rb})$ where most of the samples of the whole rock pegmatite and mineral extracts plots above the Beus line and about $30 \%$ plotting above the Gordinyenko line respectively. Overall geochemical assessment is that Egbe pegmatite is a rare metal, highly fractionated Beryl type with rare metal enrichment trend of $\mathrm{Nb}>>\mathrm{Sn}>>\mathrm{Ta}$.
\end{abstract}

KEYWORD: Pegmatite, Peraluminous, Syncollisional, Within-plate, Discriminant, Fractionation, Sample media

\section{INTRODUCTION}

The Egbe granitic pegmatite occur as dikes and vein lets of varying sizes, intruding pelitic-to-semi-pelitic schist and calc-gneiss, amphibolites, the gneissic and granitic rocks in the area. Pegmatite all over the world are known as host to gemstones and rare earth ( $\mathrm{Ta}-\mathrm{Nb}$ $\mathrm{Sn})$ metals that are of strategic importance in the present day advanced technological world. The global demand for these metals informed a renewed research interest on pegmatite geology worldwide.

Previous geochemical studies on the Nigerian pegmatite has contributed significantly to the understanding of the
Nigerian pegmatite geology (Okunlola, 1998 ; Okunlola and Ocan, 2003; Ajayi and Ogedengbe ,2003; Garba, 2003;Ekwueme,2004; Okunlola,2005; Adekeye and Akintola,2007; Okunlola \& Ocan,2009; Okunlola and Onesimus,2009; Okunola and Oyedokun , 2009; Okunlola and Oluwatosin ,2010; Okunlola and Akinola,2010 and Akintola et.al , 2012).

The Nigerian Pegmatite field that was earlier believed to span within a $400 \mathrm{~km} \mathrm{NE}-\mathrm{SW}$ trending belt (Jacobs and Webb, 1946, Wright, 1970; Kinnaird, 1984, and Kuster, 1990) was later established to spread across Nigeria (Okunlola, 1998; Garba,2002; and Okunlola, 2005) with over 3000 sizeable pegmatite bodies discovered. Also,

Aderogbin, J. A., Department of Earth Sciences, Ajayi Crowther University, Oyo State. Nigeria.

Okunlola O. A., Department of Geology, University of Ibadan, Oyo State. Nigeria. 
by Okunlola, (2009) delineated a broad-based seven pegmatite belts located in Anka-BirniGwuari, KabbaIsanlu, Nasarawa-keffi, ljero-Aramoko, Ibadan-Osogbo , Oke Ogun and Share-Lema localities. These does not preclude several minor occurrences of pegmatite identified in the southeast and northeastern part of Nigeria (Garba,2003; Okunlola, 2005). Studies revealed that the Nigerian mineralized pegmatite trends in a NESW and NNE-SSW in accordance to recognized regional fault systems (Adekeye and Akintola,2007) and are enriched in strategic metals (Okunlola, 1998). This present study is located within Latitude $8^{0} 5^{\prime} \mathrm{N}, 8^{\circ} 17^{\prime}$ $\mathrm{N}$ and Longitude $5^{\circ} 30^{\prime} \mathrm{E}, 5^{\circ} 40^{\prime} \mathrm{E}$.

The low lying quartz-feldspar-muscovite pegmatite bodies in this area intrude Older Granite host rocks. Previous studies on pegmatite geology from the Nigerian pegmatite fields indicated that pegmatite in Egbe-Isanlu pegmatite field is mineralized in $\mathrm{Nb}-\mathrm{Ta}-\mathrm{Sn}$ metals but much is not recorded on the petrogenesis of the pegmatite and the classification not documented. This study is to advance knowledge in the field of the Nigerian pegmatite occurrence as relates to the occurrence of pegmatite in Egbe meta-sedimentary terrain. In this study, the geology is discussed,

compositional characterization done and mineralization potential established.

\section{MATERIALS AND METHODOLOGY}

Systematic sampling of the pegmatite and the primary host rocks were carried out in the study area on a two week field exercise. Accessibility was made possible through untared roads, foot paths and bush cuts (Fig.1). Samples were collected strategically and properly labeled to avoid miss up during transportation to Aiayi Crowther University Geology Workshop in Oyo. Thin sections of the pegmatite and host rocks were done for petrographic studies. Twelve (12) muscovite, four (4) feldspar mineral extracts and eleven (11) whole rock pegmatite representative samples were prepared for geochemical analysis. The samples were analyzed for major and trace element using the Inductively Coupled Plasma Atomic Emission Spectrometry (ICP-AES) Instrumentation Method from Activation Laboratories Ontario, Canada. Efforts were made to ensure that the mineral extracts from only fresh pegmatite rock samples were prepared for the geochemical analysis. The representative samples were well preserved, air-dried at $60{ }^{\circ} \mathrm{C}$ and crushed to -80 mesh $(-177 \mu \mathrm{m})$ and $0.5 \mathrm{~g}$ weight from each of the prepared samples ware weighed into platinum crucible. $5 \mathrm{mls}$ of perchloric acid $\left(\mathrm{HCLO}_{3}\right)$, trioxonitrate $(\mathrm{V})\left(\mathrm{HNO}_{3}\right)$ acid and $15 \mathrm{mils}$ of hydrofluoric acid (HF) ware added, stirred thoroughly and evaporated at low temperature for some hours. The salt was dissolved by adding $4 \mathrm{mls}$ of hydrochloric acid (HCL), the solution warmed and allowed to cool before 50 mils of distilled water were added. The solution was then introduced into the ICP torch. The light emitted by the ions in the ICP was converted to electric signal by the photomultiplier in the spectrometer. The intensity of the light signal so emitted by the ions was compared to a previously measured intensity of a known concentration of the elements.

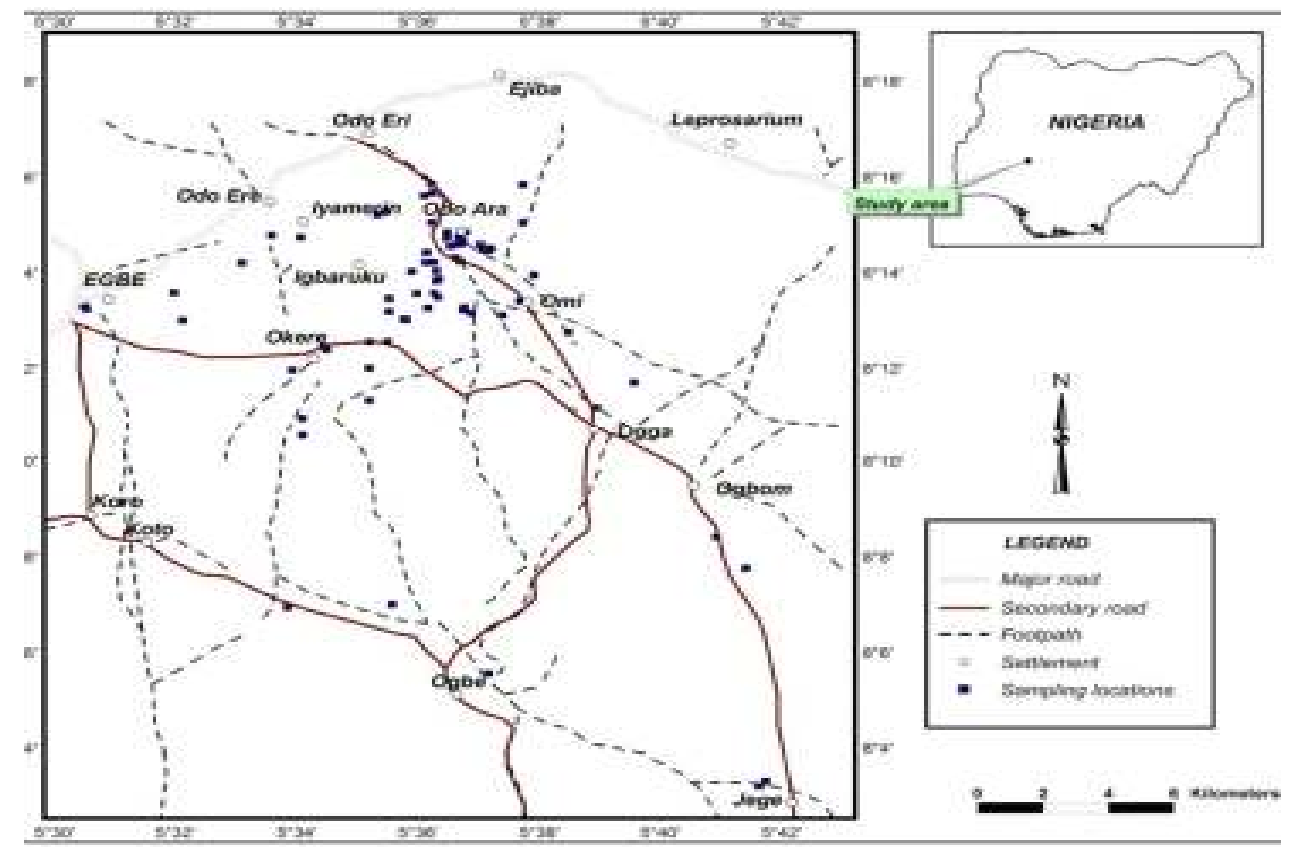

Fig. 1: Sample Location and Accessibility Map of Study Area 


\section{GEOLOGICAL SETTING, FIELD DESCRIPTION AND PETROGRAPHY}

Egbe pegmatite lies within Kabba-Isanlu pegmatite field, located in the Precambrian basement complex of southwestern Nigeria. Egbe falls within the thick southwestern rainforest zone, characterized by undulating topography creating a NE-SW trending inselberges in most places. The basement rocks of Nigeria is the product of the Pan-African Orogenic events delimited by the West African Craton, east of Congo craton (Black,1984). Lithological and geochemical evidence characterizes the rocks of the basement complex as the migmatite-gneiss complex, the schist belts and the older granites (Ogezi, 1988; Rahaman, 1988; Turner, 1983; Dada et al., 1987; Mathesis and Caen-Vachette,1983; Umeji and CaenVachette, 1984; Rahamanet al., 1988, Akande and Reynolds, 1990, Elueze,2000). The schist belt of Nigeria is a low-grade metasediments and metamorphosed pellitic and psamatic assemblages, characterized by a $\mathrm{N}-\mathrm{S}$ trending synformal troughs into migmatite-gneiss complex. The older granites consist of a wide range of rocks compositionally different from each other like tonalities, granites, granodiorites, admellites, quartz monzonites, syenites, and pegmatite (Rahaman,1988). Egbe granitic pegmatite discordantly intrudes the older granites, the migmatite-gneis and the metasedimentary rocks in the area (Fig. 2). In this study area is a N-S trending quartzite ridge that forms a continuous hill from lyamerin to Ikoro towards the southern part. The study area is generally underlain by amphibolites schists and amphibolitic rocks, biotite gneiss, banded gneiss, granite gneiss and coarse-porphyritic granite. The coarsegrain- textured porphyritic granite occur as distinct outcrop in Egbe town. The microscopic examination of the rock revealed the mineral composition and the modal percentages as quartz $(42.55 \%)$, albite $(9.86 \%)$, orthoclase $(3.28 \%)$, microcline $(13.15 \%)$, hornblende (15.70) and augite (15.70\%) respectively. The occurrence of banded-gneiss is not widespread in the study area but a mapable unit of this rock was encounter towards the eastern flange of Egbe where the mineral composition was identified from microscopic study as quartz $(36.14 \%)$, biotite $(23.24 \% 0$, microcline $(5.13 \%)$, muscovite $(21.37 \%)$, amphibole $(8.89 \%)$ and augite

$(5.13 \%)$.

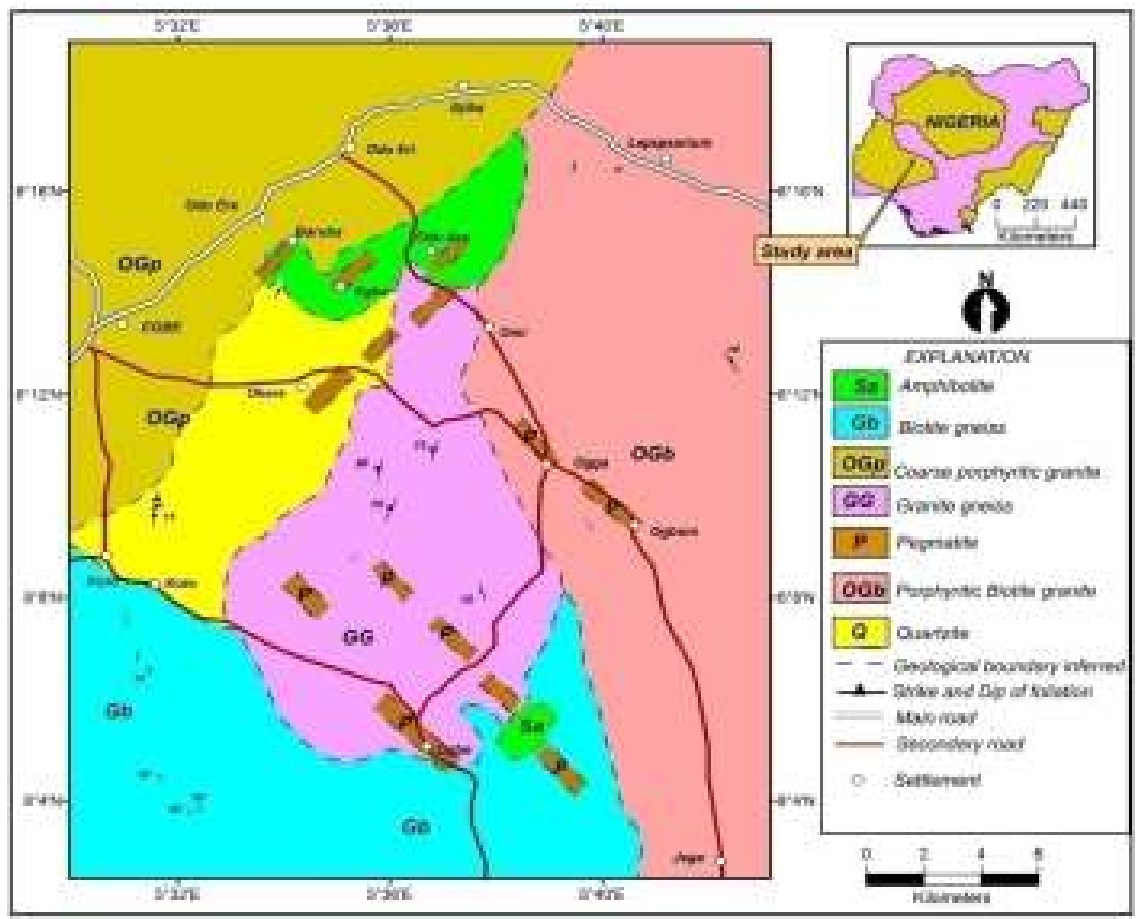

Fig. 2: Geology map of the area around Egbe

The pegmatite in the area occur as distinct dykes of varying dimension comprising quartz $(44.86 \%)$, albite $(15.05 \%)$, microcline $(11.2 \%)$, Orthoclase $(2 / 06 \%)$, muscovite $(26.92 \%)$ and accessory minerals $(0.02 \%)$ as shown in table 1 . Petrographic configuration of minerals in the pegmatite showed an irregular mass of euhedral quartz crystals with strong cross-hatched twining and variable microperthite intergrowth and large platy grains of muscovite as observed under petrographic microscope (Fig.3). 

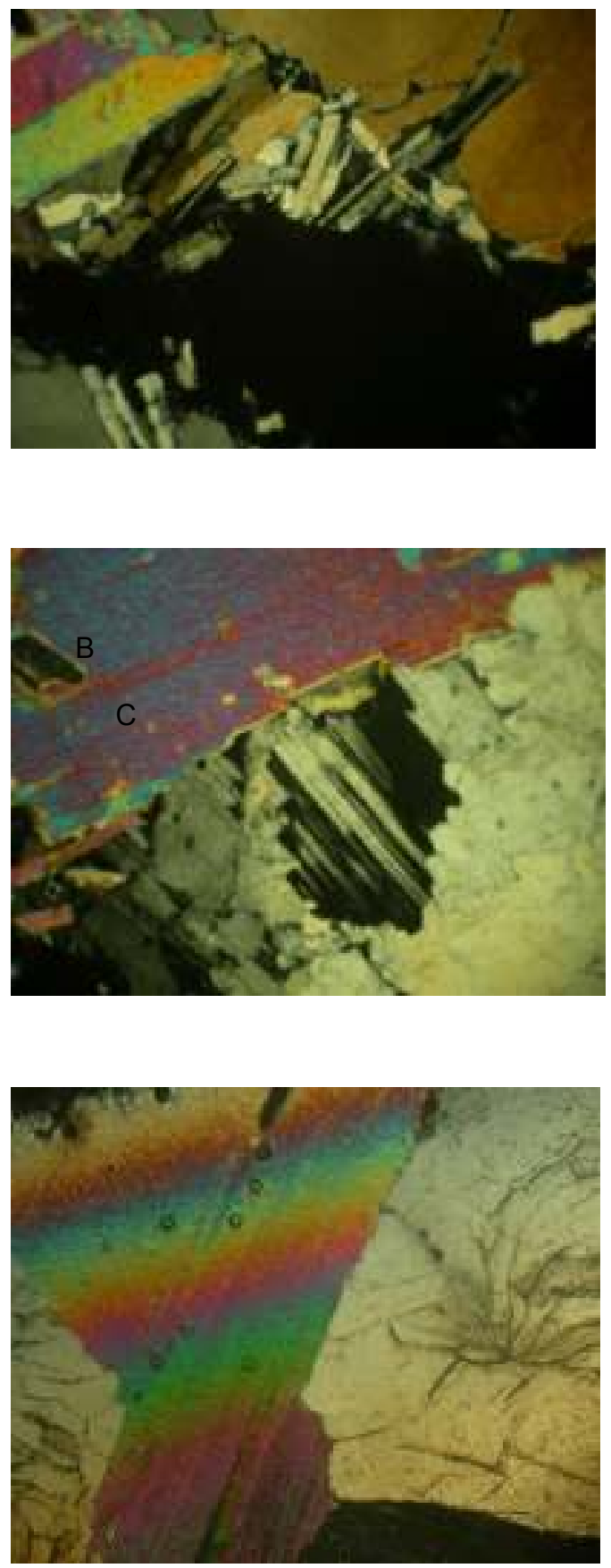

Fig.3: A, B \& C Showing Photomicrograph of pegmatite in transmitted light (cross polar) $\times 100$

Table 1: Modal Analysis of Minerals in the pegmatite

\begin{tabular}{|l|l|}
\hline Minerals & $(\%)$ \\
\hline Quartz (\%) & 44.86 \\
\hline Albite (\%) & 15.05 \\
\hline Orthoclase (\%) & 2.06 \\
\hline Microcline (\%) & 11.12 \\
\hline Muscovite (\%) & 26.92 \\
\hline Accessory minerals (\%) & 0.02 \\
\hline Total & 100.03 \\
\hline
\end{tabular}




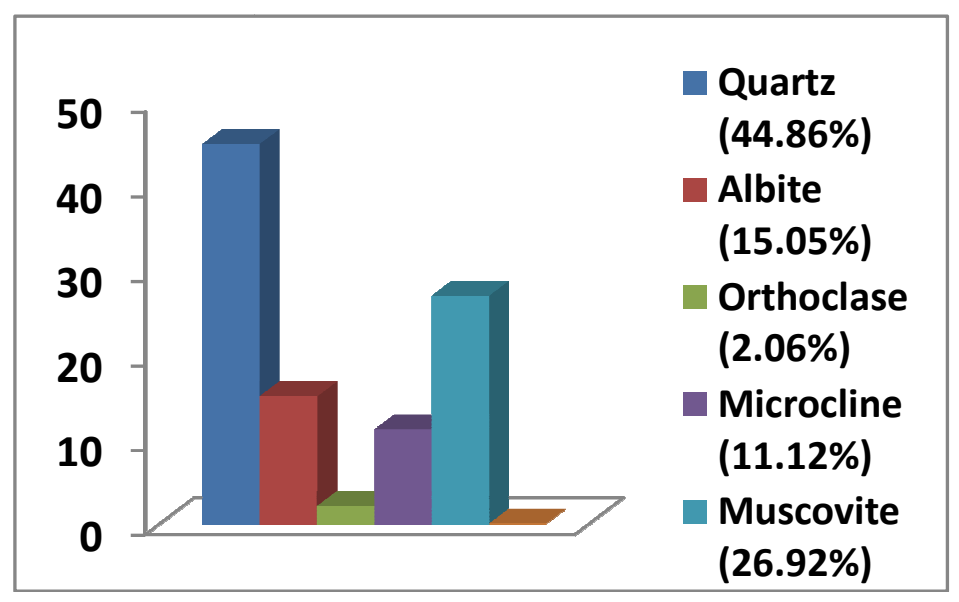

Fig.4: histogram of mineral composition of Egbe pegmatite

\section{GEOCHEMICAL FEATURES AND MINERALIZATION POTENTIAL}

The geochemical results of major and trace elements of Egbe whole rock pegmatite is presented in table 2 showing that the pegmatite is siliceous (aveg. 79.82wt\% ) with high alumina content (aveg. 12.22wt\%). Silica and alumina constitute the bulk of the oxides in the pegmatite. There is a moderately high contents of $\mathrm{K}_{2} \mathrm{O}$ (3.75wt\%) and $\mathrm{Na}_{2} \mathrm{O}(2.25 \mathrm{wt} \%)$ but $\mathrm{Fe}_{2} \mathrm{O}_{3}, \mathrm{CaO}, \mathrm{MnO}$, $\mathrm{MgO}, \mathrm{TiO}_{2}$ and $\mathrm{P}_{2} \mathrm{O}_{5}$ are each less than $1.0 \%$. The $\mathrm{K}_{2} \mathrm{O}$ content in the mineral extracts have relatively elevated values where muscovite is $7.81 \mathrm{wt} \%$ and $8,68 \mathrm{wt} \%$ in the feldspar extracts. The trend is a little different for $\mathrm{Na}_{2} \mathrm{O}$ in the mineral extracts with $1.31 \mathrm{wt} \%$ in the muscovite and $4.71 \mathrm{wt} \%$ in the feldspar extracts. These values are comparable with results from other Ta$\mathrm{Nb}$ pegmatite of Nigeria like the Oke Asa pegmatite of
$71.46 \% \mathrm{SiO}_{2}$ (Okunlola et.al, 2010) and Ago Iwoye of $73.74 \% \mathrm{SiO}_{2}$ (Akintola et.al,2011).

The trace elements in the pegmatite (Table 2) show substantial enrichment of $\mathrm{Rb}$ (1083.55ppm), $\mathrm{Nb}$ (109.35ppm) and Sn (92.27ppm) but moderately enriched in $\mathrm{Ta} \quad(52.55 \mathrm{ppm}), \quad \mathrm{Ba}(50.37 \mathrm{ppm}), \mathrm{Zr}$ (41.27ppm), U (41.0ppm), Cs (21.14ppm) and $\mathrm{Sr}$ $(17.84 \mathrm{ppm})$. In the mineral extracts, average values of trace element in muscovite extracts are $\mathrm{Rb}$ (4121.66ppm), Nb (169.90ppm), Ta (115.43ppm), Hf (0.84ppm), Sn (481.93ppm), Cs (123.73ppm), Ga (738.15ppm), Zn (738.15ppm) and feldspar extracts has average values of $\mathrm{Rb}(770.55 \mathrm{ppm}), \mathrm{Nb}(20.49 \mathrm{ppm}), \mathrm{Ta}$ (43.53ppm), Hf (0.84ppm), Sn (13.08ppm), Cs (35.28ppm), Ga (23.85ppm) and $\mathrm{Zn}(6.48 \mathrm{ppm})$. The three sample media show clear enrichment of $\mathrm{Rb}$ but moderately enriched in $\mathrm{Ta}, \mathrm{Cs}, \mathrm{Ba}, \mathrm{Zr}, \mathrm{Sr}$, and $\mathrm{Nb}$ 
Table 2: Major and Trace metals of Egbe Pegmatite and Ratios of Strategic Metals

\begin{tabular}{|c|c|c|c|c|c|c|c|c|c|c|c|c|}
\hline $\begin{array}{l}\text { Oxides } \\
\text { (wt } \%)\end{array}$ & 1 & 2 & 3 & 4 & 5 & 6 & 7 & 8 & 9 & 10 & 11 & Average \\
\hline Si $\mathrm{O}_{2}$ & 73.8 & 74.8 & 95.7 & 63.4 & 71.5 & 82.7 & 82.1 & 82.2 & 73.6 & 90.2 & 88.1 & 79.82 \\
\hline $\mathrm{Al}_{2} \mathrm{O}_{3}$ & 15.6 & 15.5 & 1.4 & 23.4 & 14.8 & 10.9 & 12.6 & 11.4 & 14.35 & 6.96 & 7.59 & 12.22 \\
\hline $\mathrm{Fe}_{2} \mathrm{O}_{3}$ & 0.14 & 0.14 & 0.23 & 1.44 & 0.06 & 0.25 & 0.89 & 0.85 & 0.18 & 0.33 & 0.25 & 0.44 \\
\hline $\mathrm{MnO}$ & 0.02 & 0.01 & 0.01 & 0.01 & 0.01 & 0.02 & 0.02 & 0.01 & 0.01 & 0.05 & 0.03 & 0.02 \\
\hline $\mathrm{MgO}$ & 0.02 & 0.03 & 0.03 & 0.05 & 0.01 & 0.01 & 0.29 & 0.07 & 0.01 & 0.01 & 0.01 & 0.05 \\
\hline $\mathrm{CaO}$ & 0.19 & 0.2 & 0.01 & 0.02 & 0.08 & 0.07 & 0.05 & 0.01 & 0.29 & 0.01 & 0.01 & 0.09 \\
\hline $\mathrm{Na}_{2} \mathrm{O}$ & 7.17 & 6.08 & 0.05 & 0.54 & 1.91 & 0.68 & 0.36 & 0.26 & 7.16 & 0.27 & 0.23 & 2.25 \\
\hline $\mathrm{K}_{2} \mathrm{O}$ & 0.88 & 1.17 & 0.27 & 6.3 & 10.0 & 2.45 & 3.45 & 2.24 & 0.53 & 1.72 & 1.89 & 2.81 \\
\hline $\mathrm{P}_{2} \mathrm{O}_{5}$ & 0.18 & 0.12 & 0.07 & 0.02 & 0.02 & 0.05 & 0.02 & 0.22 & 0.22 & & 0.01 & 0.09 \\
\hline LOI & 1 & 1.3 & 0.9 & 4.44 & 0.1 & 4.89 & 1.8 & 1.3 & 1.7 & 1.0 & 1.79 & 1.84 \\
\hline Total & 99.00 & 99.35 & 98.67 & 99.62 & 98.49 & 102.02 & 101.58 & 98.56 & 98.05 & 100.55 & 99.91 & 99.2 \\
\hline \multicolumn{13}{|c|}{ Trace Elements (ppm) } \\
\hline $\mathrm{Ta}$ & 113 & 167.5 & 2.1 & 64.2 & 0.4 & 53.7 & 31.8 & 40.5 & 15.7 & 46.6 & 42.6 & 52.55 \\
\hline Cs & 9.44 & 9.21 & 0.96 & 19.6 & 7.76 & 23.3 & 26.6 & 80.1 & 3.33 & 24.5 & 27.7 & 21.14 \\
\hline $\mathrm{Rb}$ & 423 & 531 & 104 & 2350 & 480 & 1640 & 1485 & 1890 & 251 & 1320 & 1445 & 1083.55 \\
\hline Sn & 135 & 69 & 10 & 159 & 4 & 116 & 149 & 208 & 16 & 64 & 85 & 92.27 \\
\hline $\mathrm{Nb}$ & 64.1 & 57 & 6.9 & 233 & 233 & 32.7 & 425 & 42.5 & 38.7 & 36.9 & 33 & 109.35 \\
\hline $\mathrm{Sr}$ & 37.7 & 22.9 & 4.7 & 13 & 66.7 & 4.9 & 27.7 & 1 & 8.1 & 2.5 & 7 & 17.84 \\
\hline $\mathrm{Y}$ & 1.9 & 0.5 & 0.7 & 0.7 & 53.7 & 1 & 46 & 2.1 & 0.9 & 0.5 & 0.5 & 9.86 \\
\hline $\mathrm{Ba}$ & 8.6 & 16.7 & 28.1 & 57.2 & 269 & 9.3 & 129 & 8.5 & 14.1 & 3.5 & 11.2 & 50.47 \\
\hline $\mathrm{Hf}$ & 5.1 & 1.1 & 0.2 & 1.1 & 1 & 1.8 & 4.6 & 120 & 0.5 & 0.4 & 0.4 & 12.38 \\
\hline Th & 3.6 & 1.28 & 0.31 & 1.53 & 3.16 & 0.6 & 0.46 & 7.7 & 1.59 & 0.11 & 0.24 & 1.87 \\
\hline W & 1 & 1 & 1 & 13 & 1 & 1 & 6 & 5 & 1 & 1 & 1 & 2.91 \\
\hline $\mathrm{Zr}$ & 25 & 2 & 2 & 8 & 19 & 23 & 32 & 337 & 2 & 2 & 2 & 41.27 \\
\hline $\mathrm{Ga}$ & 31.7 & 28.3 & 4.7 & 21.5 & 17.3 & 40.2 & 40.6 & 65.6 & 29.5 & 36.7 & 37.2 & 32.12 \\
\hline $\mathrm{Zn}$ & 9 & 10 & 8 & 92 & 5 & 62 & 29 & 53 & 15 & 103 & 65 & 41 \\
\hline $\mathrm{U}$ & 1.64 & 0.63 & 0.05 & 0.74 & 2.3 & 0.31 & 0.64 & 11.8 & 0.43 & 0.18 & 0.16 & 1.721 \\
\hline $\mathrm{K}$ & 7304 & 9711 & 2241 & 52290 & 83000 & 20335 & 28635 & 18592 & 4399 & 14276 & 15687 & 23315 \\
\hline $\mathrm{Na}$ & 53194 & 45108 & 371 & 4006 & 14170 & 5045 & 2671 & 1929 & 53120 & 2003 & 1706 & 16666 \\
\hline \multicolumn{13}{|l|}{ Ratios } \\
\hline $\mathrm{K} / \mathrm{Rb}$ & 17.27 & 18.29 & 21.55 & 22.25 & 172.92 & 12.40 & 19.28 & 9.84 & 17.53 & 10.82 & 10.86 & 30.27 \\
\hline $\mathrm{Rb} / \mathrm{Sr}$ & 11.22 & 23.19 & 22.12 & 180.77 & 7.196 & 334.69 & 53.61 & 1890 & 30.99 & 528 & 206.43 & 298.93 \\
\hline $\mathrm{Na} / \mathrm{Rb}$ & 124.06 & 83.80 & 3.52 & 1.68 & 29.12 & 3.03 & 1.77 & 1.007 & 208.78 & 1.49 & 1.16 & 41.77 \\
\hline $\mathrm{Na} / \mathrm{K}$ & 7.18 & 4.58 & 0.16 & 0.08 & 0.17 & 0.24 & 0.09 & 0.10 & 11.92 & 0.14 & 0.11 & 2.25 \\
\hline $\mathrm{Ba} / \mathrm{Rb}$ & 0.02 & 0.03 & 0.27 & 0.02 & 0.56 & 0.006 & 0.087 & 0.0045 & 0.056 & 0.003 & 0.008 & 0.097 \\
\hline $\mathrm{Zr} / \mathrm{Hf}$ & 4.90 & 1.82 & 10 & 7.27 & 19 & 12.77 & 6.96 & 2.81 & 4 & 5 & 5 & 7.23 \\
\hline $\mathrm{Sr} / \mathrm{Rb}$ & 0.09 & 0.04 & 0.045 & 0.006 & 0.14 & 0.003 & 0.017 & 0.0005 & 0.03 & 0.002 & 0.005 & 0.034 \\
\hline $\mathrm{Rb} / \mathrm{Sr}$ & 11.22 & 23.18 & 22.13 & 180.77 & 7.19 & 334.69 & 53.61 & 1890 & 30.99 & 528 & 206.43 & 298.93 \\
\hline $\mathrm{Rb} / \mathrm{Cs}$ & 44.81 & 57.65 & 108.33 & 119.89 & 61.86 & 70.39 & 55.82 & 23.59 & 75.38 & 53.88 & 52.17 & 65.80 \\
\hline $\mathrm{Ta} / \mathrm{W}$ & 113 & 167.5 & 2.1 & 4.94 & 0.4 & 53.7 & 5.3 & 8.1 & 15.7 & 46.6 & 42.6 & 41.81 \\
\hline $\mathrm{K} / \mathrm{Cs}$ & 773.73 & 1054.39 & 2334.37 & 2667.85 & 10695.88 & 872.74 & 1076.504 & 232.11 & 1321.02 & 582.69 & 566.32 & 2016.15 \\
\hline $\mathrm{Nb} / \mathrm{Ta}$ & 0.57 & 0.34 & 3.29 & 3.63 & 582.50 & 0.61 & 13.36 & 1.05 & 2.46 & 0.79 & 0.77 & 55.40 \\
\hline
\end{tabular}


Table 3: Average Values of Trace Metals (ppm) in

Whole Rock Pegmatite and Mineral Extracts

\begin{tabular}{|c|c|c|c|}
\hline & Whole rock pegmatite & Muscovite extracts & Feldspar extracts \\
\hline Ta & 52.55 & 106.719 & 43.525 \\
\hline Cs & 21.14 & 118.575 & 35.275 \\
\hline $\mathbf{R b}$ & 1083.55 & 4086 & 1385.25 \\
\hline Sn & 92.27 & 428.019 & 13.075 \\
\hline Nb & 109.35 & 163.875 & 20.488 \\
\hline $\mathrm{Sr}$ & 17.84 & 12.538 & 9.5 \\
\hline $\mathbf{Y}$ & 9.86 & 1.469 & 0.153 \\
\hline $\mathrm{Ba}$ & 50.47 & 126.825 & \\
\hline $\mathrm{Hf}$ & 12.38 & 0.806 & 0.843 \\
\hline Th & 1.87 & 0.793 & 0.933 \\
\hline $\mathbf{W}$ & 2.91 & 10.594 & 0.366 \\
\hline $\mathrm{Be}$ & - & 20.583 & 35 \\
\hline $\mathrm{Zr}$ & 41.27 & 4.226 & 8.1 \\
\hline Ga & 32.12 & 570.567 & 23.85 \\
\hline $\mathbf{Z n}$ & 41 & 198.331 & 6.475 \\
\hline $\mathbf{U}$ & 1.721 & 0.6231 & 0.3 \\
\hline $\mathrm{Ti}$ & 2.92 & 14.1 & \\
\hline $\mathrm{Cu}$ & 5.09 & 6.413 & 5.138 \\
\hline Li & & 373.092 & 16.7 \\
\hline $\mathrm{Ag}$ & 1 & 76.2 & 28 \\
\hline Co & 1.414 & 1.966 & \\
\hline $\mathrm{Cr}$ & 12.727 & 6.75 & 2.75 \\
\hline Mo & 2 & 1.156 & 0.09 \\
\hline $\mathrm{Ni}$ & 5 & 3.352 & 0.475 \\
\hline $\mathrm{Pb}$ & 5.364 & 5.985 & 16.29 \\
\hline $\mathbf{V}$ & 5.545 & 4.293 & \\
\hline Mn & - & 601.636 & 45.25 \\
\hline As & - & 1.8125 & 1.5 \\
\hline
\end{tabular}

Egbe pegmatite is enriched in $\mathrm{Nb}, \mathrm{Ta}, \mathrm{Rb}, \mathrm{Sn}$, and $\mathrm{Cs}$ (Table 2) which suggests possible mineralization of this pegmatites in the rare metal columbo-tantalite minerals (Moller and Morteani, 1987). A common anomaly found in pegmatites according to Heier and Taylor, (1959b), is low K/Rb ratio (less than 100 ppm) suggesting a $\mathrm{Rb}$ - enriched-pegmatite where the pegmatite is rich in $\mathrm{Rb}$ but deficient in $\mathrm{K}$.

The pegmatite manifests characters typical of Lithium, Caesium and Tantalite (LCT) pegmatite family with $\mathrm{Li}$, $\mathrm{Rb}, \mathrm{Cs}, \mathrm{Ga}, \mathrm{Sb}>\mathrm{N},(\mathrm{B}, \mathrm{P}, \mathrm{F})$ and the silisic with peraluminous $(A / C N K>1)$ character points to the LCT granitic family for the pegmatite (Cerny, 1992 and London,2005). Solodove, (1971) and Cerny, $(1982,1991 a, 1991 b)$ reported that the origin of the LCT granitic pegmatite family was derived from the intrusion of pegmatitic fluids into schists and gneissic host rocks. Schistose rocks are ductile and this probably influenced the fracture-filling-dykelike pegmatite occurrence in Egbe field. Egbe dyke-like pegmatite bodies intrudes schistose host and other older granite rocks in the study area. The Maniar and Piccoli,(1989) plot of A/NK vs A/CNK further elucidated the peraluminous nature of the pegmatite as shown in Fig.5 where the whole rock pegmatite samples and mineral the extracts plots in the peraluminous field. The $\mathrm{Rb}(\mathrm{ppm}) \mathrm{Vs} \mathrm{Rb} /(\mathrm{Y}+\mathrm{Nb})$ discriminant plot for the pegmatite after Pearce et al., (1984) presented in Fig.6, classifies the pegmatite within a mixed origin of syncollisional (SCG), within plate granite (WPG) orogenic granite (ORG) fields.

According to Kuster, (1990), a moderately low K/Rb ratio sugests a late stage progressive fractionation crystallization and mineralization which Egbe pegmatite satisfies. Also, plot of K/Rb Vs Rb (Fig 7) seperates fractionation sequence and barren from mineralised pegmatite while $\mathrm{K} / \mathrm{Rb} \mathrm{Vs}$ Cs plots the samples in the rare metal pegmatite field (Fig.8). Extreme fractionation of lithophile elements like $\mathrm{Rb}$ and $\mathrm{Cs}$ is a common geochemical feature of granitic pegmatite (Garba,2003)). Okunlola and Oyedokun, (2009) further expounded on Garba's finding that the extreme fractionation of lithopile element is expecially peculiar to rare metal ( $\mathrm{Ta}-\mathrm{Nb}$ ) bearing pegmatites. Egbe pegmatite samples recorded a moderately low value of $\mathrm{K} / \mathrm{Rb}$ ratio (Table 2 ) which favorably compares with rare metal pegmatites of Nigeria suggesting, that Egbe pegmatite is extremely fractionated and probably originated from a product of late stage progressive fractionation cryatallization of the source magma. The ratio of $\mathrm{Ta} / \mathrm{W}$ plotted against Cs (Fig. 9) for Egbe pegmatite indicates that $\mathrm{Ta} / \mathrm{W}$ ratio increases with increasing elemental fractionation of $\mathrm{Cs}$ and this satisfies the findings of Moller and Morteani, (1987)

The correlation plot (Fig.10) of major and trace elements ( $\mathrm{Ta} / \mathrm{Ta}+\mathrm{Nb})$ vsMn/ (Mn+Fe) after Cerny, (1991) for whole rock pegmatite and mineral extracts classifies the 
pegmatites as mineralized and of the Be-bearing family. The pegmatite belongs to the LCT petrogenetic family (Li, Rb, Cs,Be, Ga, Sn, Ta 2 N (BPF) and Beryl sub type. Previously, Cerny, (1992) reported that the LCT family of pegmatite has a mild to extremely peraluminous granitic parent composition which is confirmed from plot of $\mathrm{Al}_{2} \mathrm{O}_{3} / \mathrm{Na}_{2} \mathrm{O}+\mathrm{K}_{2} \mathrm{O}$ Vs $\mathrm{Al}_{2} \mathrm{O}_{3} / \mathrm{CaO}+\mathrm{Na}_{2} \mathrm{O}+\mathrm{K}_{2}$ Ofor Egbe Wholee Rock Pegmatite in fig.11 (after Maniar and Piccoli,1989).

The pegmatite whole rock, muscovite and feldspar extracts plots within the $\mathrm{Ta}-\mathrm{Nb}$ mineralization line of Beus (1966) and Gordiyenko (1971). The Ta vs. Ga plot (Beus,1966) Fig.12, Ta vs Rb (Morteani,1987) Fig.13 and Ta vs K/Cs (Gordinyenko,1971) Fig.14 establishes Egbe pegmatite as potentially mineralized.

The mineralization potential of the pegmatite of Egbe area was further evaluated using the plot Ta vs Cs (fig. 15) and Ta vs Cs+Rb (Fig.16) and both plots indicated a positive mineralization potential for the pegmatite.

High $\mathrm{LiO}_{2}$ content in muscovite $\left(>1.0\right.$ wt. $\left.\% \mathrm{LiO}_{2}\right)$ is believed to be generally peculiar to muscovite from Spodumene $\left(\mathrm{LiAlSi}_{2} \mathrm{O}_{6}\right)$ carrying pegmatite, petalite or
Li-phosphates (Wise and Brown, 2010). It was further reported by the authors that pegmatite carrying Columbite and Cassiterite group of minerals in their muscovite extracts are generally enriched in Tin to the tune of between 25 to 1800 ppm (Table 3)

Columbite $(\mathrm{Fe}, \mathrm{Mn})(\mathrm{Nb}, \mathrm{Ta})_{2} \mathrm{O}_{6}$ is a common mineral in granitic pegmatite and Cassiterite are niobium- tantalite to tantalum - rich mineral. The moderately enriched values of these metals in the muscovite extracts from Egbe pegmatite is an indication that the pegmatite is probably mineralized in the Lithium- bearing minerals like Spodumene. Jacbson and Webb (1946) earlier reported the potential of Egbe-Isanlu pegmatite as a columbite -tantalite to Cassiterite minerals - carrying source rock.

According to Wise and Brown (2010), high values of Cesium are suggestive of high magmatic fractionation peculiar to Pollucite-bearing pegmatite. Pollucite $\left(\mathrm{CsAl}{ }_{4} \mathrm{Si}_{9} \mathrm{O}_{26} \cdot \mathrm{H}_{2} \mathrm{O}\right)$ occurrence in pegmatite is characteristic of pegmatite of complex mineralogical composition.

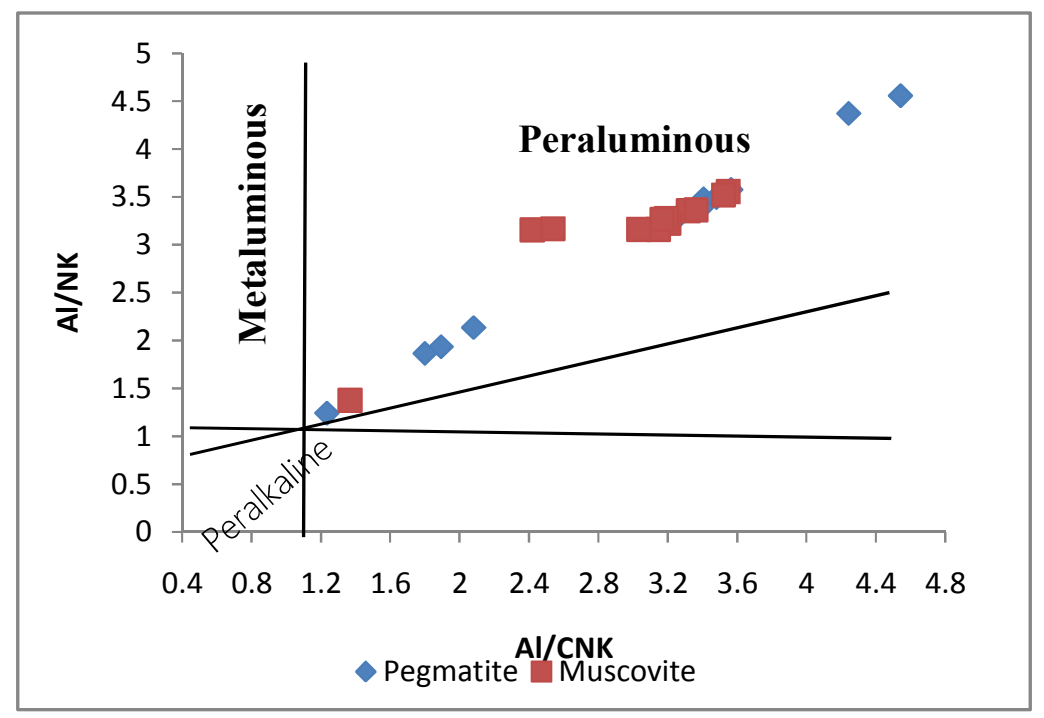

Fig. 5: A/NK vs A/CNK for Egbe pegmatite and Muscovite Extracts (Maniar and Piccoli,1989)

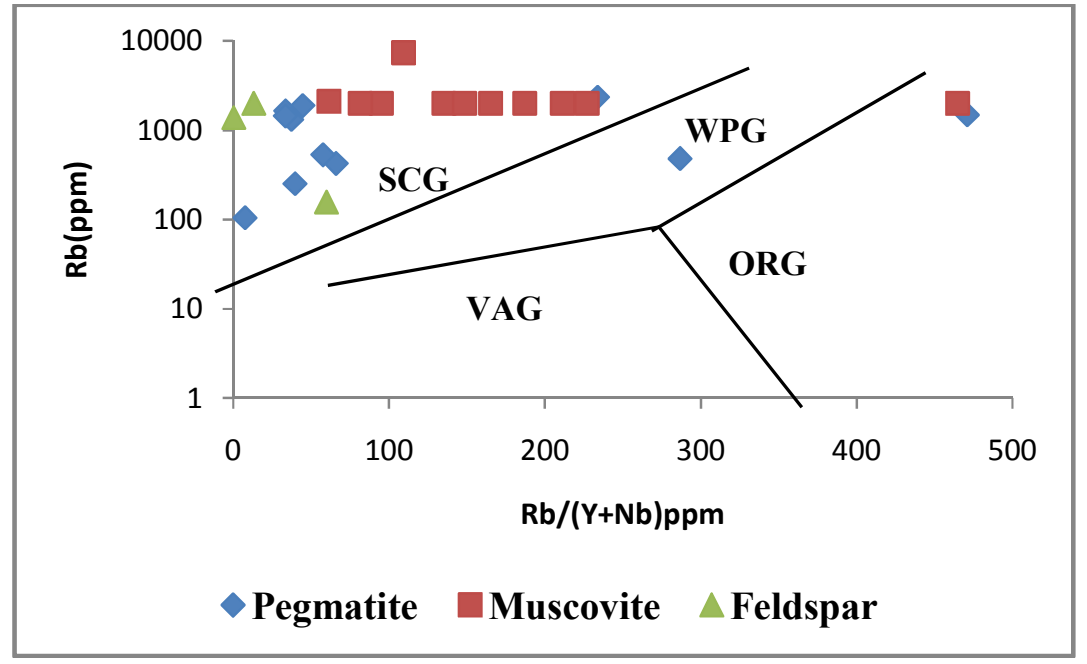

Fig 6: The Rb vs Rb/(Y+Nb) discriminant plot for the sample media (After Pearce et al., 1984). VAG-VOLCANIC ARC GRANITE; ORGOCEANIC RIDGE GRANITE; WPG-WITHIN-PLATE GRANITE; SCG-SYN-COLLISIONAL 


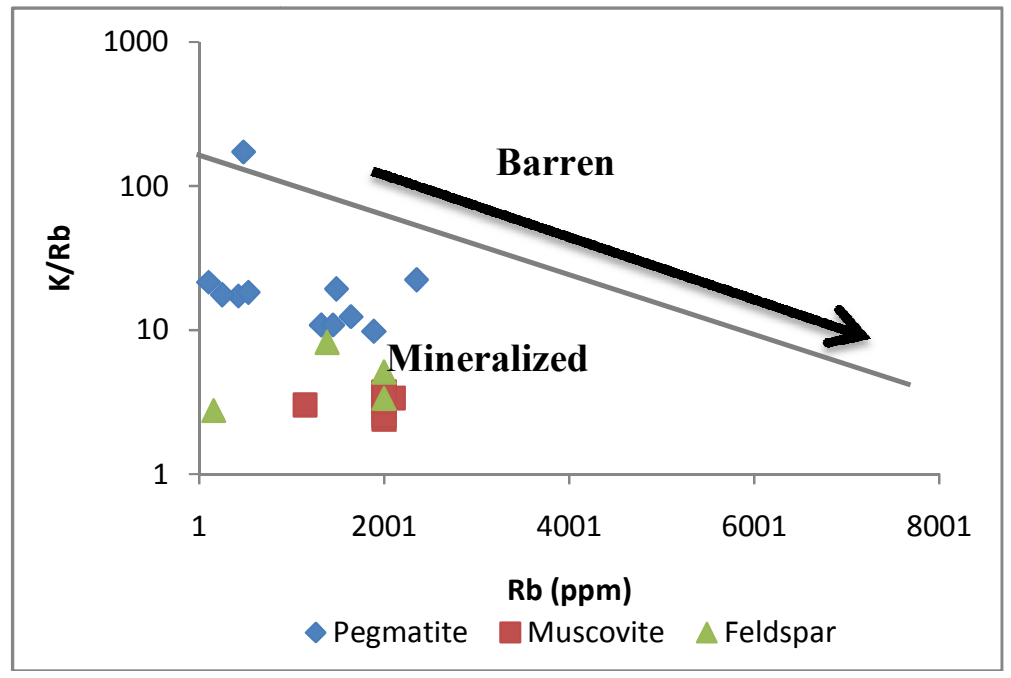

Fig. 7: Plot of K/Rb vs Rb for Whole Rock Pegmatite and Mineral Extracts of Egbe Pegmatite after Staurov et. al, (1969)

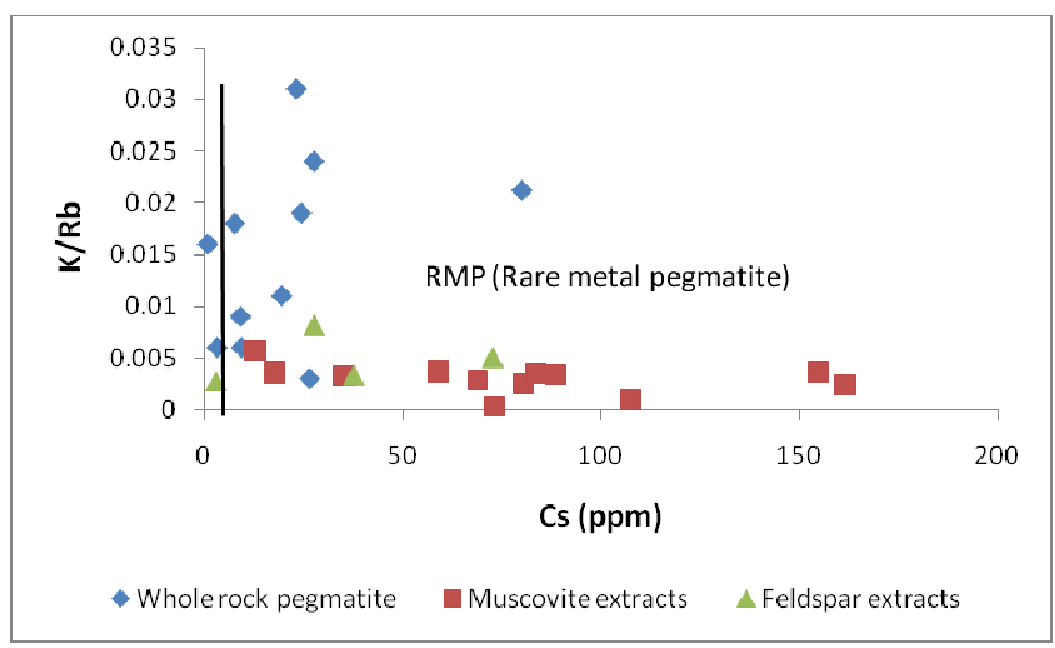

Fig.8: Plot of K/Rb vs Cs for whole rock pegmatite and mineral extracts ( After Cerny, 1982 )

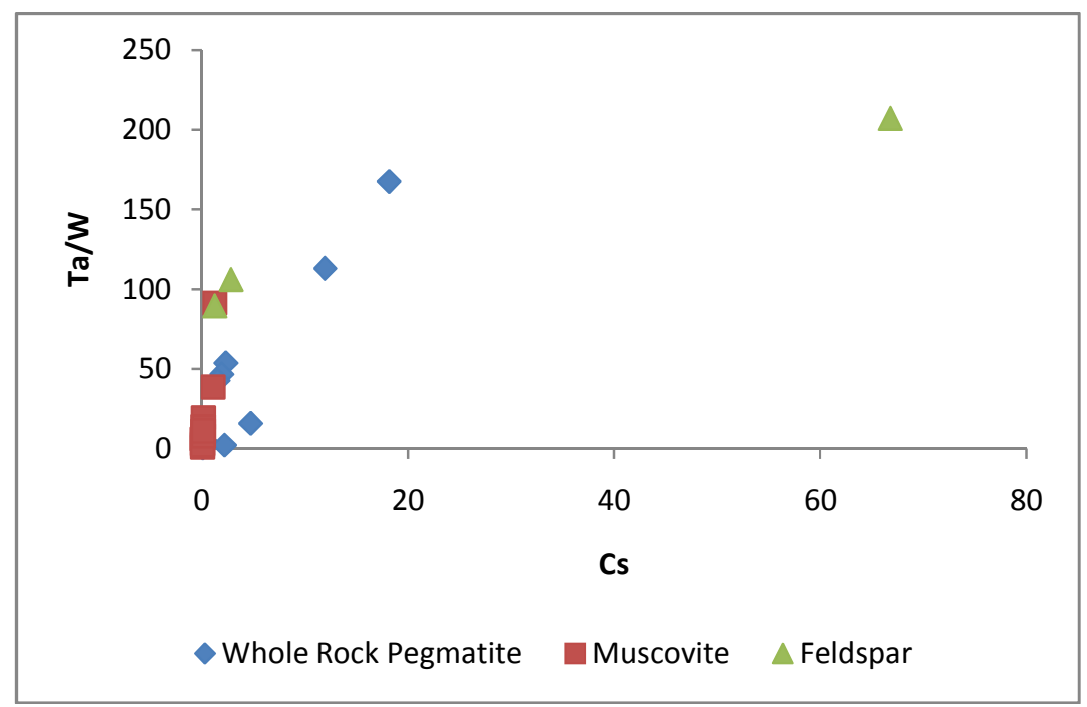

Fig.9: Plot of Ta/W ratio vs. Cs for Egbe Pegmatite and mineral extracts 


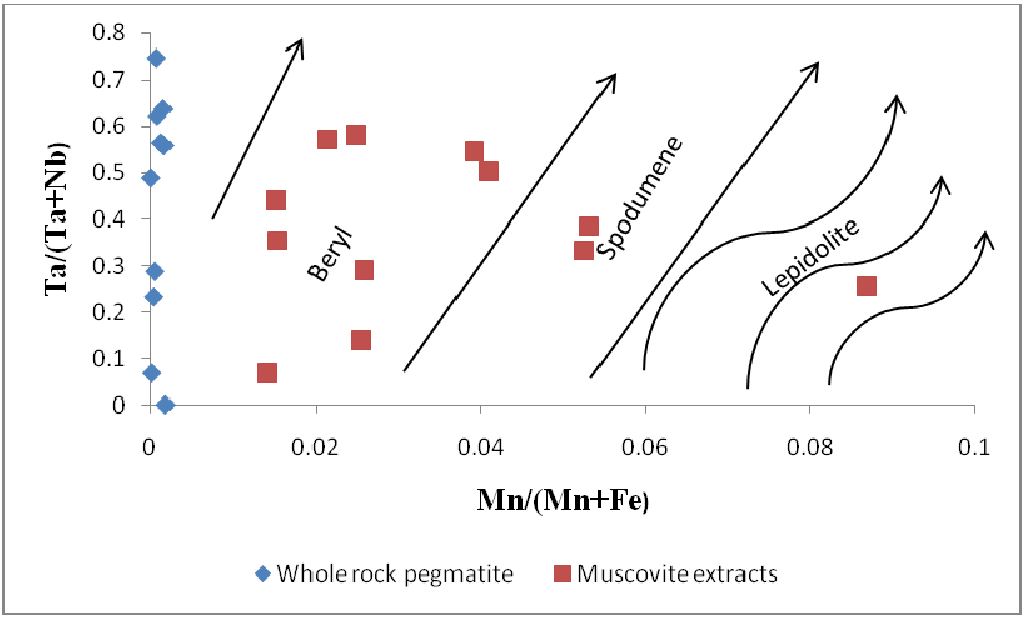

Fig.10: $\mathrm{Ta} /(\mathrm{Ta}+\mathrm{Nb})$ vs $\mathrm{Mn} /(\mathrm{Mn}+\mathrm{Fe})$ after Cerny, (1991)

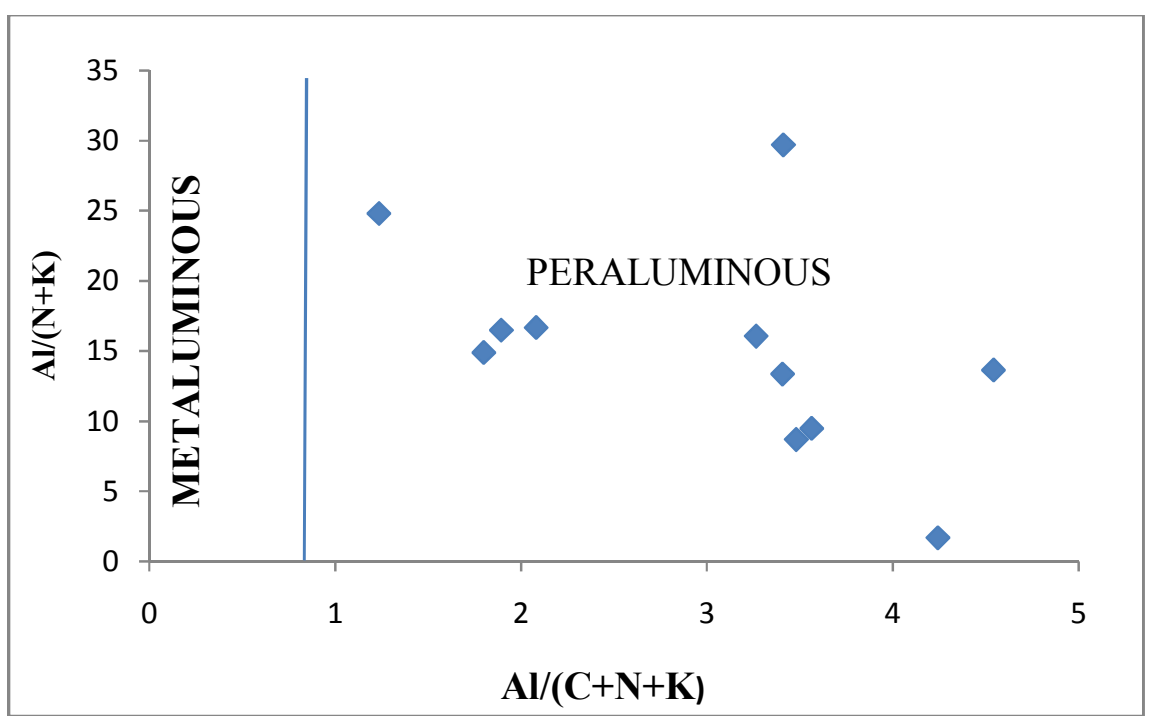

Fig.11: Plot of $\mathrm{Al}_{2} \mathrm{O}_{3} / \mathrm{NA}_{2} \mathrm{O}+\mathrm{K}_{2} \mathrm{O}$ Vs $\mathrm{Al} / \mathrm{CaO}+\mathrm{Na}_{2} \mathrm{O}+\mathrm{K}_{2} \mathrm{O}$ (after Maniar and Piccoli, 1989)

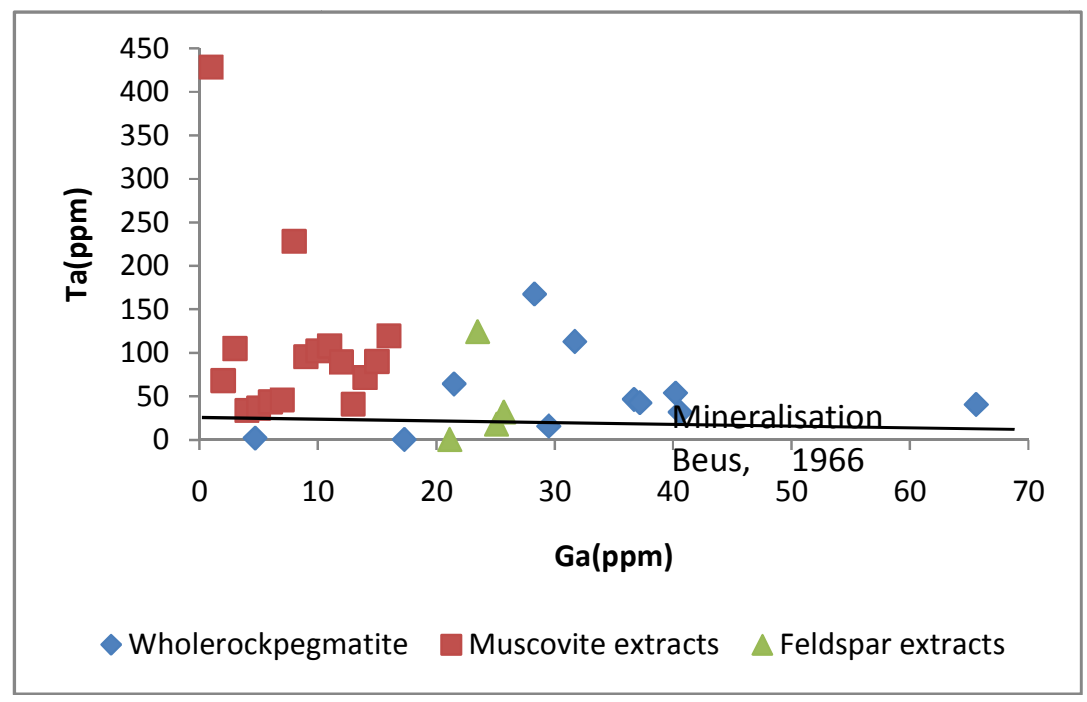

Fig. 12:- plot of Ta (ppm) vs Ga (ppm) after Beus, 1966 


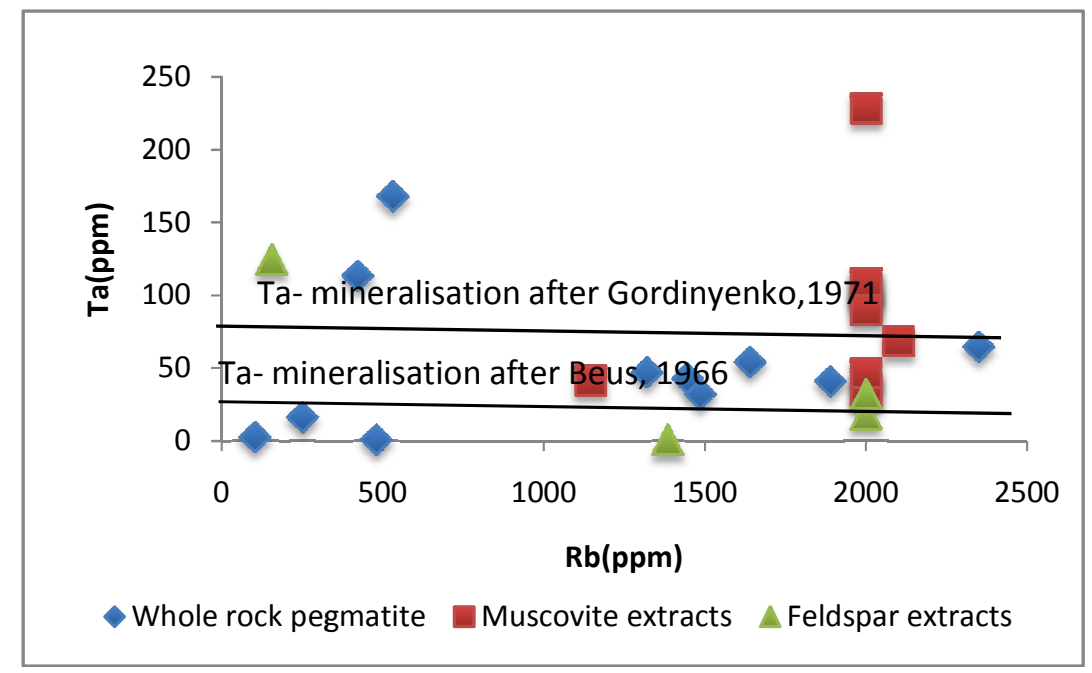

Fig. 13:- Plot of Ta (ppm) vs Rb (ppm) after (Morteani, 1987)

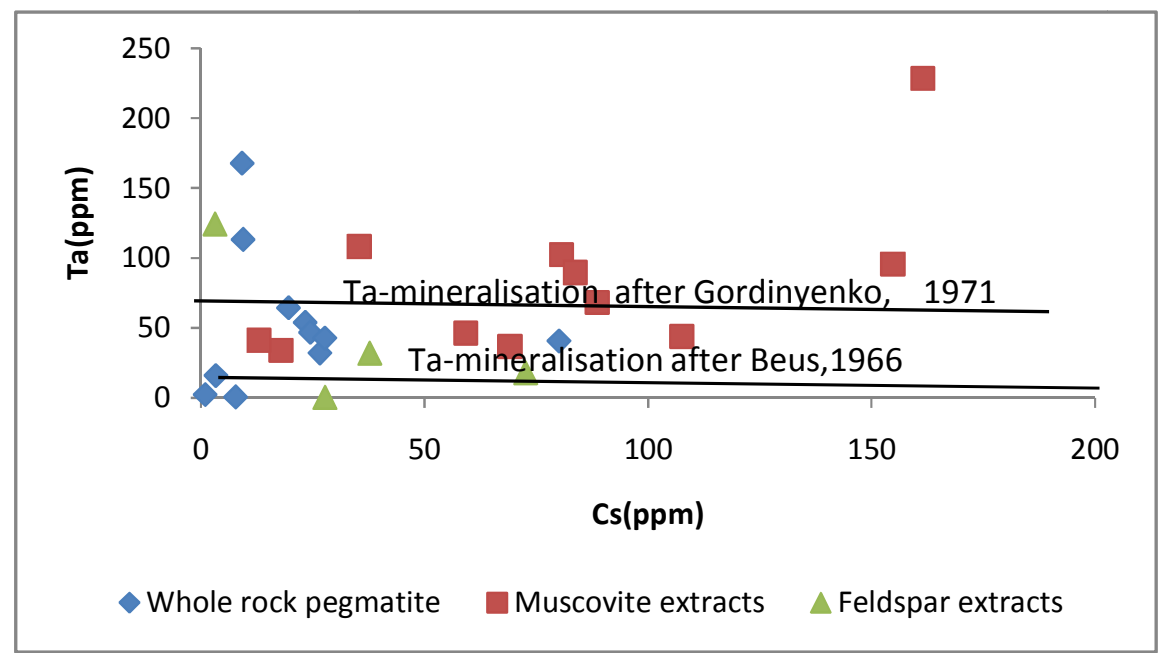

Fig. 14 :- Ta vs Cs for Whole rock pegmatite and miner

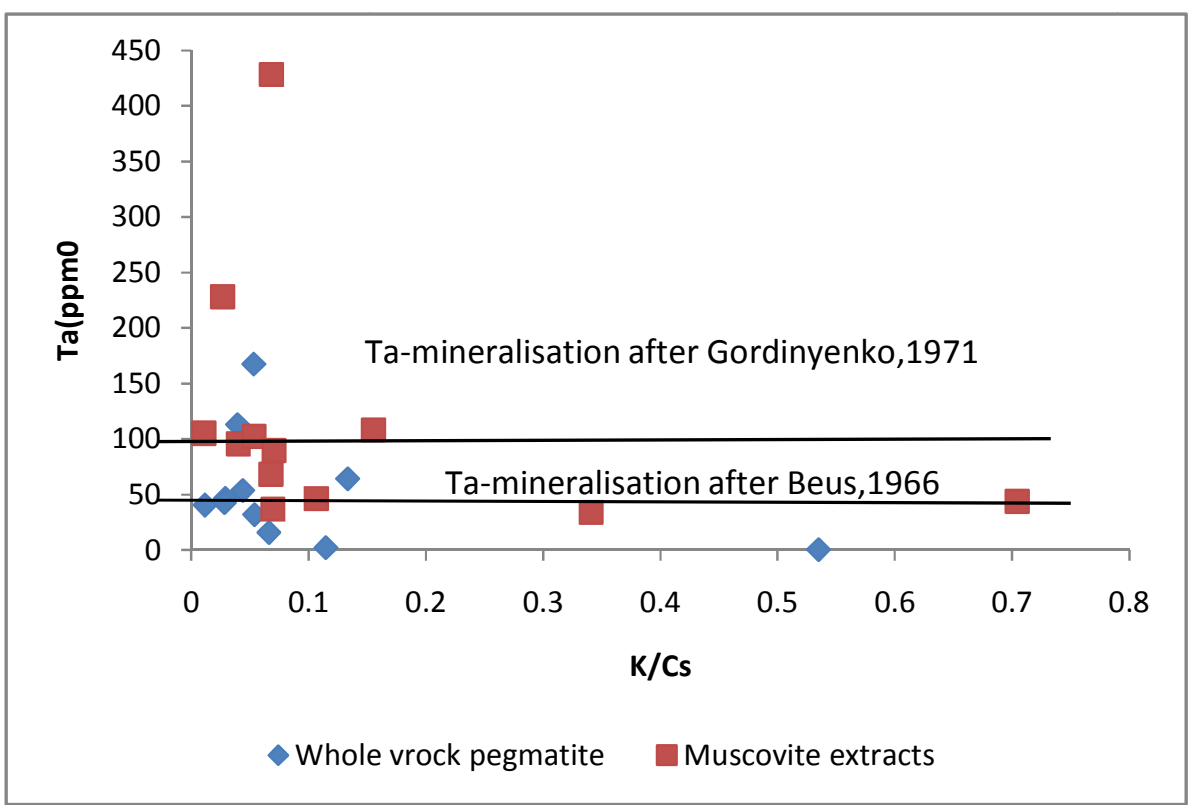

Fig. 15: Plot of Ta vs K/Cs for Whole rock pegmatite, Muscovite and Feldspar Extracts of Egbe Pegmatite (after Gordinyenko, 1971) 


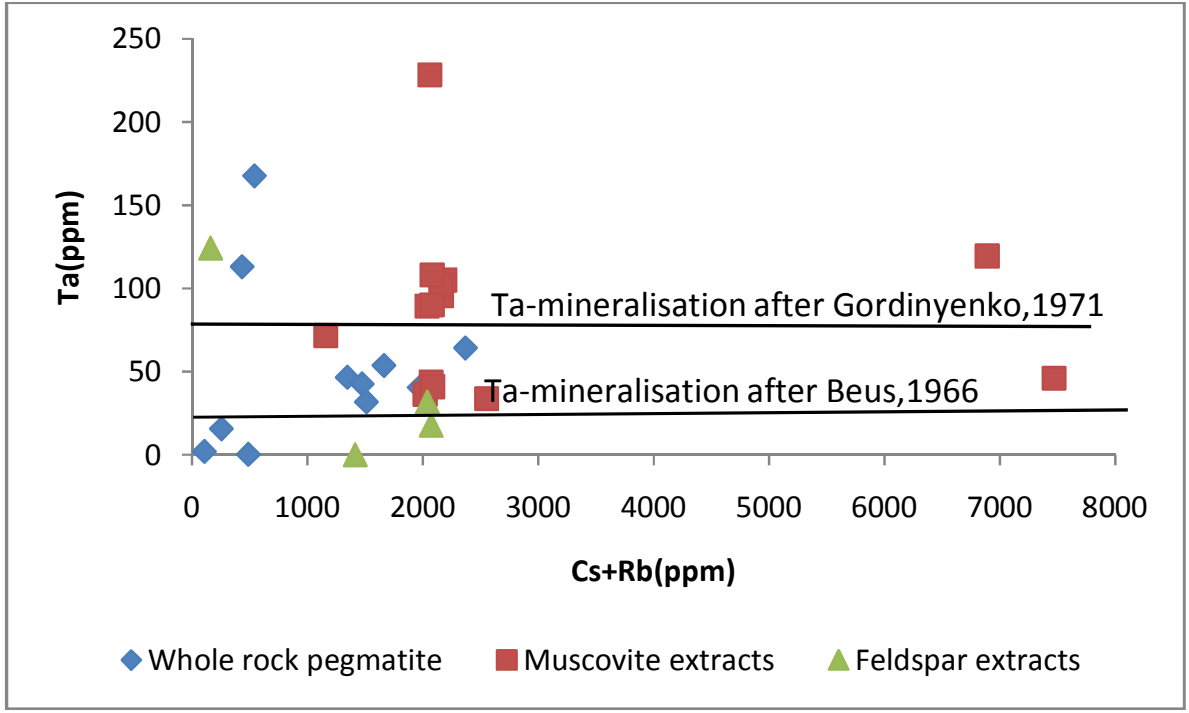

Fig. 16: Plot of Ta vs Cs+Rb for Whole rock pegmatite, Muscovite and Feldspar Extracts of Egbe Pegmatite (after Gaupp et. al, 1984)

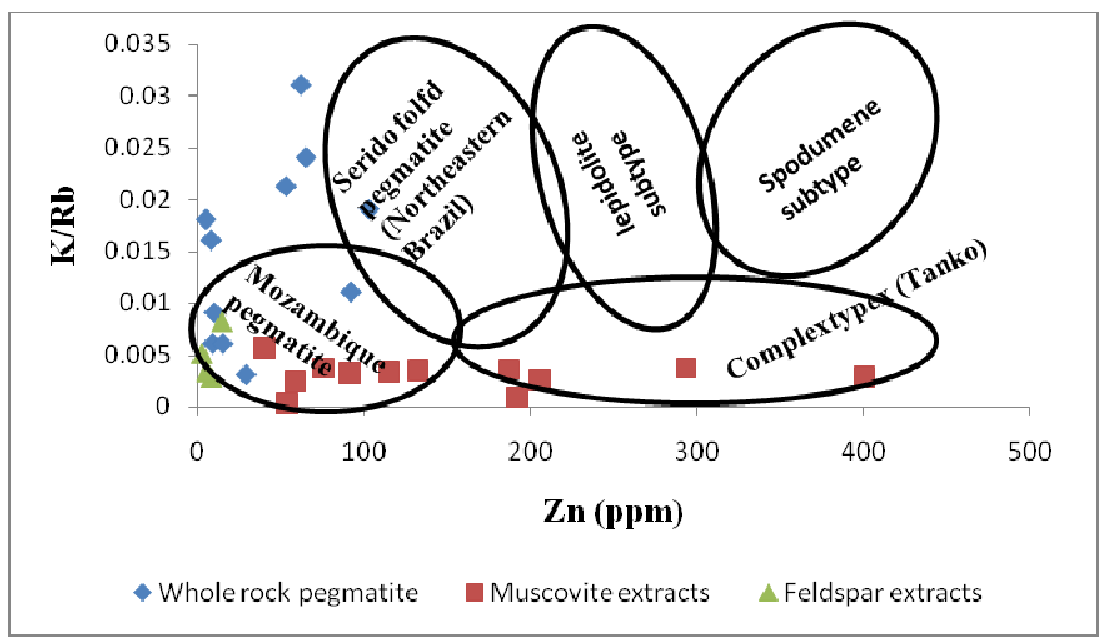

Fig. 17: Plot of Ta/ (Ta+Nb) vsMn/ (Mn+Fe) after Cerny, (1991a; 1991b)

For Egbe whole rock pegmatite and mineral extract (after Baumgartner, 2001)

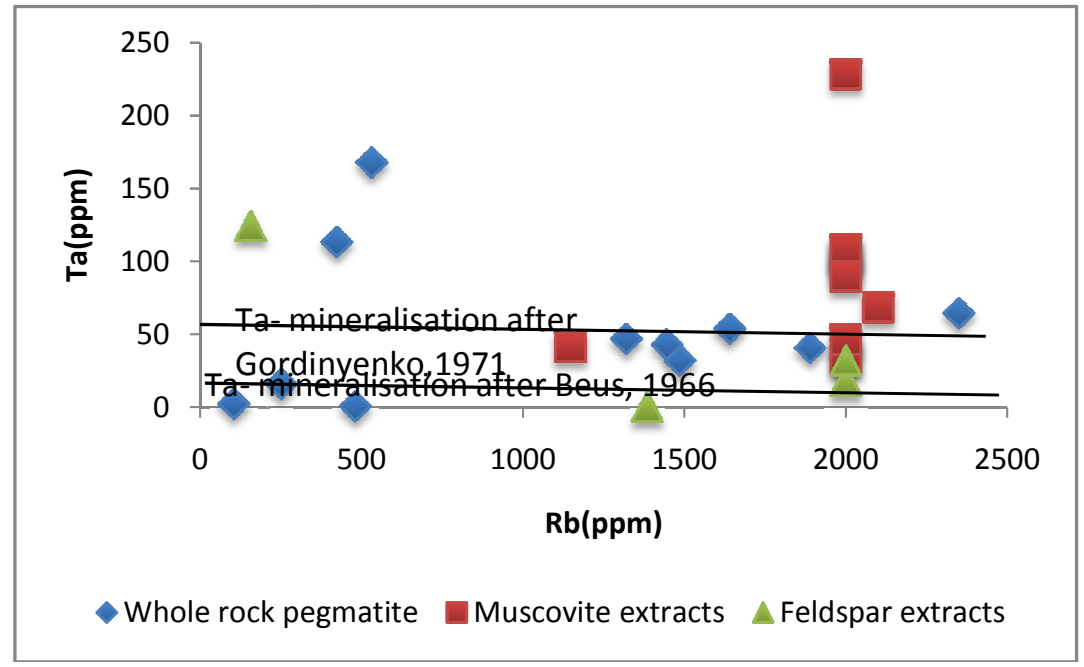

Fig. 18:- plot of Ta (ppm) vs Rb (ppm) 


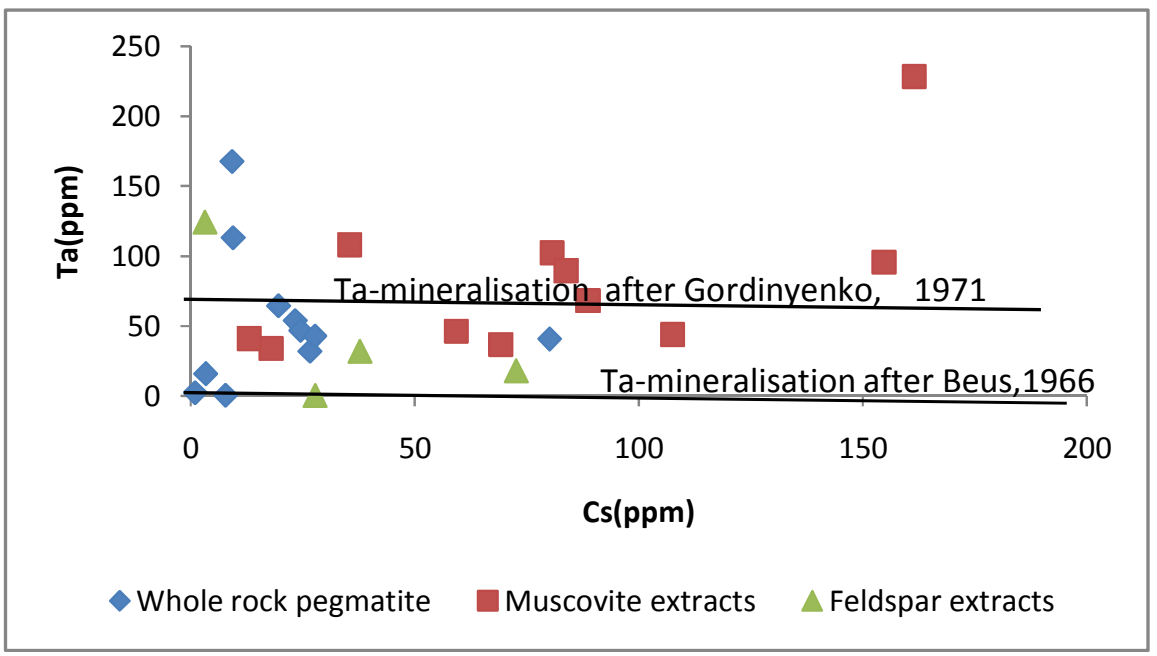

Fig. 19 :- Ta vs Cs for Whole rock pegmatite and mineral Extracts of Egbe Pegmatite after Cerny, (1991)

\section{CONCLUSION}

The plot of $\mathrm{A} / \mathrm{CAN}>1$ and $\mathrm{Al}_{2} \mathrm{O}_{3}>\mathrm{CaO}+\mathrm{Na}_{2} \mathrm{O}+\mathrm{K}_{2} \mathrm{O}$ coupled with enrichment of $\mathrm{SiO}_{2}, \mathrm{Al}_{2} \mathrm{O}_{3}, \mathrm{Na}_{2} \mathrm{O}$, and $\mathrm{K}_{2} \mathrm{O}$ and depletion of $\mathrm{Fe}_{2} \mathrm{O}_{3}, \mathrm{MnO}_{2}$ and $\mathrm{MgO}$ values suggests that Egbe pegmatite is of peraluminous bulk composition. The correlated samples of whole rock pegmatite, muscovite and feldspar extracts plots above the Beus and the Gordinyenko lines using the discrimination plots of $\mathrm{Ta}$ vs $\mathrm{Rb}, \mathrm{Ta}$ vs $\mathrm{KCs}$, Ta vs Cs and $\mathrm{Ta}$ vs $(\mathrm{Cs}+\mathrm{Rb})$. Also the plots of $\mathrm{Ta} / \mathrm{W}$ vs $\mathrm{Cs}$ for whole rock pegmatite, muscovite and feldspar extracts show that they are clearly discriminated with more enrichment of the rare metals in the muscovite extracts. The coarse nature of the quartz, muscovite and feldspar in Egbe pegmatite could make separation by handsorting and air floatation methods an asset to mineral processors. Quartz is a major phase in Egbe granitic pegmatite and it could be processed to produce ultra high purity quartz that can be of value in electronic industries and for high purity quartz glass.

Overall geochemical assessment show that the Egbe pegmatite is highly fractionated with enrichment and are mineralized with $\mathrm{Ta}>>\mathrm{Nb}>>\mathrm{Sn}$.

\section{REFERENCE.}

Adekeye, J. I. D. and Akintola, O.F, 2007. Geochemical features of rare metal pegmatites in Nasarawa area, Central Nigeria. J. Min. and Geology. 43(1):15-21. Published by the Nigerian Mining and Geosciences Society

Ajayi T.R, and Ogedengbe, O., 2003. Exploitation of precious and rare metals in Nigeria. Prospects for investment in mineral resources of Southwestern Nigeria, (ed.) Pp.15-26.

Akande and Reynolds, 1990.
Akintola A. I., Ikhane, P. R., Okunlola O. A., Akintola, G. O., and Oyebolu, O.O., 2012. Petrographic and Geochemical evaluations of Rare metal ( $\mathrm{Ta}$ $\mathrm{Nb}$ ) potentials of Precambrian Pegmatite of Awo area, Southwestern Nigeria.

Beus, A. A., 1966. Geochemistry of beryllium and genetic types of beryttium deposits [in transl.]. Freeman, San Francisco.

Black, R., 1984. Precambrian of West Africa. Episodes 3-8

Cerny, P., 1991. Fertile Granites of Precambrian rare element pegmatite fields: is geochemistry controlled by tectonic setting or source lithologies?. Precambrian Res. 51 429-468.

Cerny, P., 1992. Geochemical and petrogenetic features of mineralization in rare-element granitic pegmatites in the light of current research. Applied Geochemistry, 7 393-416.

Dada et al., 1987. DADA SS, LANCELOT JR, BRIQUEU. I., 1987: Age and origin of a PanAfrican charnockitic complex: $\mathrm{U}-\mathrm{Pb}$ and $\mathrm{Rb}-\mathrm{Sr}$ evidence from the charnockitic complex at Toro, Northern Nigeria. Abtr. Vol. 14 Coll.Afri. Geol. Berlin, 72-73.

Ekwueme, B. N., 2004. Pan-African Schist of Southeastern Nigeria and their relationship with Schists of Cameroon. Book of Abstracts $40^{\text {th }}$ Nigerian Mining and Geosciences Society. International Conference, Maiduguri, 18.

Elueze, A. A., 2000.Compositional appraisal and petrogenetic significance of Imelu banded ferrugineous rock in the llesha schist belt, south western Ni9gerian. Jon. Min. Geol., 36(1), pp 918. 
Garba I., 2003. Geochemical discriminat of newly discovered rare- metal bearing and barren pegmatites the Pan-African (600 $\pm 150 \mathrm{MA})$ basement of Northern Nigeria. Applied Earth set. Transaction of Institute of mining and Metathergy.13 Vol 112 pp 287-289.

Garba, I., 2002. Late Pan African tectonics and the origin of gold mineralization and rare metal pegmatites in the Kushaka schist belt, North Western Nigeria, Journal of Min. and Geol.Vol.38 (1) pp1-12.

Gaupp, R., Mormn, P. and Monrnenr, G., 1984.TantalPegmatite, Geologische, petrologischeund Geochemische Untersuchungen, Monograph Series on Minerol Deposits 23,Borntraeger,Berlin.

Gordiyenko, V. V., 1971. Concentration of Li, Rb, and Cs in potash feldspar and muscovite as criteria for assessing the rare metal mineralization in granitic pegmatites. International Geological review, Vol.13, pp134-142.

Heier, K. S. and Taylor, S. R., 1959b. Distribution of Ca, $\mathrm{Sr}$ and $\mathrm{Ba}$ in southern Norwegian pre-Cambrian alkali feldspars. Geochim, et Cosmoch, Acta 17:286 - 304.

Jacobson J. and Webb J.B.,1946. The pegmatite of Central Nigeria Bulletin No 17,Geological survey of Nigeria.

Kainnard. J. A., 1984.Contrasting styles of Sn-Nb-Ta mineralization in Nigeria. J. of Afri. Earth Sci..Vol2.No.2 pp81-90.

Kuster D.,1990. Rare metal pegmatites of wamba, central Nigeria their formation in relation to late pan -African granites. Mineral deposite, Vol 2528.

Maniar, P. D. and Piccoli, P. M., 1989.Tectonic Discrimination of Granitoids. The Geological Society of America, 101, 635-643. http://dx.doi.org/10.1130/00167606(1989)101<0635:TDOG>2.3. CO;2.

Matheis, G and Caen-Vachette., 1983. Rb-Sr isotopic study of Rare metal bearing and barren pegmatites in the Pan African reactivation zone of Nigeria. J. of African Earth Sciences, $35-40$.

Ogezi, A. E. 1988. "Impact of Mining on Nigeria Environment". In: FEPA MONOGRAPH 2: Towards Pollution Abatement in Nigeria. FEPA: Lagos, Nigeria.
Okunlola. O. A., 1998.Specialty metal potentials of Nigeria. A first Mining in Nigeria Conference and Workshop for Nigerian Mineral Appraisal and Monetization programme.

Okunlola, O. A., 2005.Metallogeny of Ta-Nb mineralization of Precanberian pegmatite of Nigeria, mineral wealth, 137/2005, PP 38-50.

Okunlola , O. A. and Akintola , A. I., 2010. Geochemical features and rare metal ( $\mathrm{Ta}-\mathrm{Nb}$ ) potentials of Precambrian Pegmatite of Sepeteri area, southwestern Nigeria. Ife Journal of Science; Vol. 9, No. 2, pp. 203-214.

Okunlola, O. A., and. Ocan, O. O., 2009. Rare metal $(\mathrm{Ta}-\mathrm{Sn}-\mathrm{Li}-\mathrm{Be})$ distribution in Precambrian pegmatite of Keffi area, Central Nigeria.

Okunlola, O. A., and O. Oyedokun, M. O., 2009. Compositional trends and rare metal (Ta-Nb) mineralization potential of pegmatite and associated lithology of Igbetiarea , Southwestern Nigeria.

Rahaman, M. A., 1988. Recent Advances in the Study of the Basement Complex of Nigeria. In: Precambrian Geology of Nigeria, Oluyide, P. O., W. C. Mbonu, A. E. Ogezi, I. G. Egbuniwe, A. C. Ajibade and A. C. Umeji (Eds.). Geological Survey of Nigeria, Kaduna, Nigeria, pp: 11-43. Rahaman,1972.

Rahaman, M. A., Ajayi, T. R, Oshin, I. O., and Asubiojo F. O., 1988. Trace Element Geochemistry and Geotectonic Setting of the Ife schist belt. Pres geology Nigeria GSN public. Kaduna, PP241256.

Staurov, O. D., L. S. Stolyarov, and E. I. Isochewa., 1969. Geochemistry and Origin of Verkhlset Granitoid Massif in Central Ural Geochem Intern.6:1138-1146.

Turner, D. C. 1983. Upper Proterozoic Schist Belts in the Nigerian sector of the Pan-African province of West African. Precambrian Research. 21: 5579.

Umeji, A. C. and Caen-Vachette, M., 1984. Geochronology of Pan-Africa Nassarawa. Eggonand Mkar---Gboko granites, southeast Nigeria. Precambrian Res.

Wright. J., 1970. Control of mineralization in the older and younger tin field of Nigeria. Economic geology65,

$\mathrm{Pp}$

943-951 